\title{
Zircon in charnockitic rocks from Rogaland (southwest Norway): Petrogenetic implications
}

\author{
J.C. DUCHESNE ${ }^{1}$, R. CARUBA ${ }^{2}$ and P. IACCONI ${ }^{3}$
}

'Laboratoires Associés de Géologie, Pétrologie et Géochimie, Université de Liège, B-4000 Sart Tilman (Belgium)

Laboratoire de Géologie-Géochimie, UA., CNRS 725, Parc Valrose, F-06034 Nice Cédex (France)

'Laboratoire d'Émission Électronique et de Luminescence. Parc Valrose. F-06034 Nice Cédex (France)

\section{LITHOS}

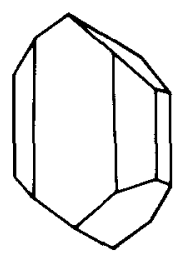

Introduction

The morphology of zircon in granitoids has provided numerous petrogenetic indications. However, few studies have been devoted to zircon in charnockitic rocks. This may be due to poor development of recognizable crystal faces (Pasteels and Michot, 1975; Wielens, 1979), but also to the great complexity of rock evolution in granulite facies conditions.

The present paper deals with various mineralogical properties of zircon in igneous and metamorphic charnockitic rocks from southwestern Norway, and discusses them in terms of the chemistry and petrogenesis of the host rocks.

\section{The problem of charnockites*}

Intermediate to acidic charnockites occur in various geological settings in SW Norway (Fig. 1). In the Rogaland igneous complex, the upper part of the Bjerkreim-Sokndal layered lopolith is made up of quartz mangerites and charnockites and a number of intrusions are monzonoritic; the Eia-Rekefjord massif, on the southwest flank of the lopolith, the Apophysis, along the southeastern border between the anorthosites and the metamorphic envelope, and numerous dykes cutting across all massifs ( $\mathrm{J}$. Michot and Michot, 1969). Layers or bodies of quartz

\footnotetext{
${ }^{*}$ Rock nomenclature after Streckeisen (1974).
} 


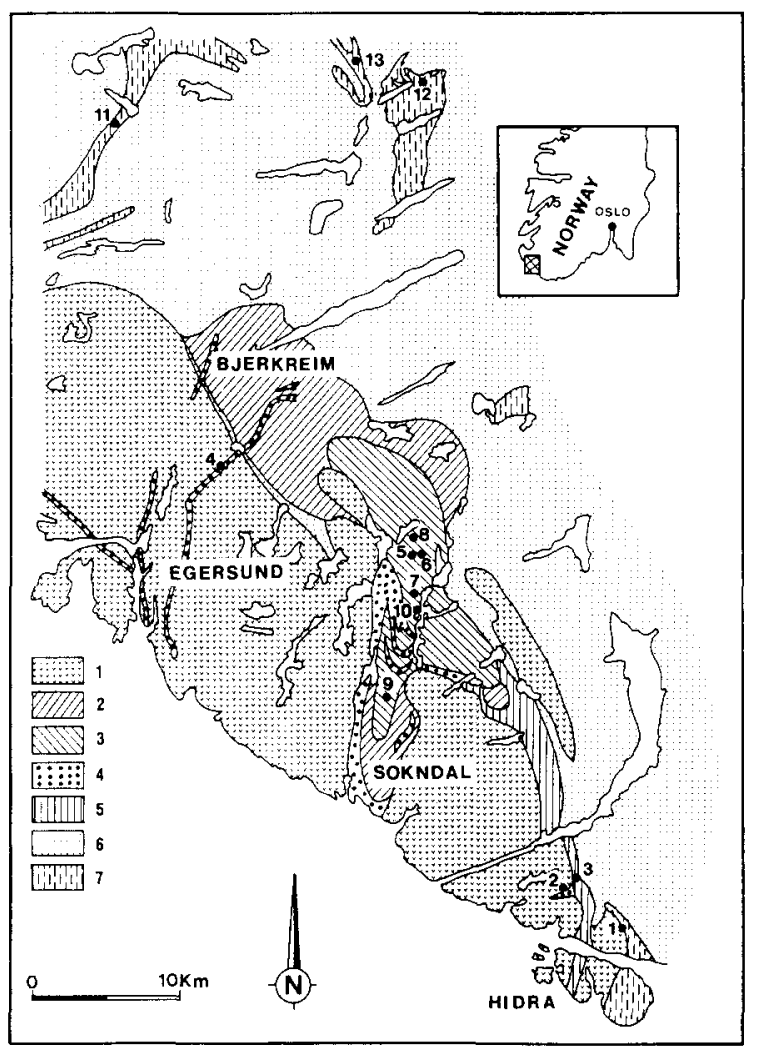

Fig. 1. Schematic geological map of the South Rogaland province (after P. Michot, 1960, 1966; J. Michot and Michot, 1969; Hermans et al., 1975). Legend: $1=$ undifferentiated anorthosite massifs; 2 =anorthosite, leuconorite and norite (lower part of the Bjerkreim-Sokndal lopolith); $3=$ mangerite and quartz mangerite (upper part of the Bjerkreim-Sokndal lopolith); $4=$ monzonorite (Eia-Rekefjord intrusion, dykes); $5=$ monzonoritic complex (Apophysis); $6=$ undifferentiated high-grade metamorphic rocks; $7=$ gneissic charnockitic intrusions. Numbers = sample number and location.

mangeritic gneisses are intercalated in the granulite facies terranes (P. Michot, 1960, 1966; Hermans et al., 1975).

The main question concerning the petrogenesis of charnockitic rocks in Rogaland is still controversial. Although it is generally agreed (Morse, 1983) that, when associated in time and space with massif-type anorthosites, acidic rocks are cogenetic with the anorthosites, it remains to be seen whether they are produced by differentiation of the same magma or whether they represent a different magma. The two-magma hypothesis was first proposed by Buddington (1939) and is now a classical interpretation for most cases (Emslie, 1978). On the other hand, P. Michot $(1960,1965)$, in his study of the Bjerk-
reim-Sokndal intrusion, postulated the existence within the same layered body of the complete series of rocks from anorthosites to quartz mangerites, with all transition members of leuconoritic, noritic and mangeritic composition. Bjerkreim-Sokndal gave strong evidence in favour of the comagmatic origin of the two types of rocks. However, isotopic studies (Demaiffe et al., 1979) showed that the acidic rocks of the lopolith have a Sr isotopic ratio distinctly higher than the more basic members of the series. Although Morse (1983) has shown that some fractionation can take place between $\mathrm{Sr}$ isotopes in the last stage of crystallization of anhydrous melts, the increase in the $\mathrm{Sr}$ isotopic ratio was taken as evidence of some contamination, in the last stages of the crystallization, with material coming from the envelope. Trace element modeling was, however, unable to unravel the mechanism of contamination: assimilation, hybridization with anatectic melts or isotopic re-equilibration by fluid circulation. On the other hand experimental evidence has been provided (Wendlandt, 1981) in favour of the formation of charnockitic rocks by partial fusion under $\mathrm{H}_{2} \mathrm{O}$-deficient or $\mathrm{CO}_{2}$-saturated conditions. This strongly supports the twomagma hypothesis since quartz mangerites could thus be produced directly by anatexis.

The typical fayalite + quartz association found in Bjerkreim-Sokndal also occurs in charnockitic gneisses of the envelope. The latter are however strongly deformed and ages as old as $1200 \mathrm{Ma}$ have been found in the Gloppurdi massif (Wielens et al., 1981), which are distinctly older than the Bjerkreim-Sokndal $950 \mathrm{Ma}$ age (Pasteels et al., 1979). Since no anorthositic event at $1200 \mathrm{Ma}$ is known in the area, it is difficult to relate the formation of this charnockitic magma to anorthosite, and it is therefore tempting to postulate an origin by anatexis.

Monzonoritic rocks associated with anorthosites are classically considered as residual after the formation of massif-type anorthosites. In southwest Norway, P. Michot $(1960,1965)$ and Wiebe (1984) related the Eia-Rekefjord intrusion and the dyke system to the differentiation of the lopolith. These views were not confirmed by Duchesne et al. (1985) who showed that a single magma could not give rise to all dykes and intrusions, and that differentiation processes toward acidic products could take place within dykes. Monzonorites also occur as pillow-like inclusions (Wiebe, 1984) in the Apophysis and in 
TABLE 1

Sample location and description

1. 7234: Hidra, road to Itland, LK592-605*. Fine-grained ( $<500 \mu \mathrm{m})$, granular, two-pyroxenes, biotite-bearing monzonorite (Duchesne ct al.. 1974)

2. 7207: Hogstad, road Kvanvig-Hogstad, LK551-626. Monzonorite with feldspar phenocrysts $(1 \mathrm{~mm})$ in a fine-grained matrix

3. 72124: Kvanvig, road N44, LK558-634. Coarse-grained monzonite with subporphyric aggregates of microperthites

4. 64104: Klungland, road N9, LK300-903. Monzonorite of the Lomland dyke (Duchesne et al., 1985)

5. 737610 and 6. 7314: Langetjörn, road to Langhus, LK434-849 and LK437-850. Fine-grained granular quartz monzonite, occurring as sharply-bounded, rounded inclusions in quartz mangerite

7. 64110: S. Ljösvatn, road to Steine, LK437-821. Coarse-grained (1 $\mathrm{cm}$ ) hypersthene quartz mangerite. Mesoperthites in irregular mosaic with remnants of corroded plagioclase. Poikilitic orthopyroxene containing the other mafic minerals. Large patches of poikilitic amphibole $(10 \mathrm{~cm})$ locally present

8. 73776: N. Langetjörn, road to Dyping, LK435-859. Ibid. sample No. 7 .

9. 66261: Kvitefjell. LK420-755. Fayalite-bearing quartz mangerite. Regular mosaic of mesoperthite with interstitial quartz and mafic minerals

10. 6687: Steine. LK441-812. Ibid. sample No. 9

11. 72145b: Gloppurdi, erratic from cliff fall, LL428-177. Fayalitebearing quartz metaleucomangerite with mesoperthite. Heterogranular, slightly foliated texture

12. 6810: E. Solheim, LL211-127. Ibid. sample No. 11

13. 72 146: Fossankrå. N. Veen, LL379-186. Mesocratic clinopyroxene olivine monzonite gneiss

*NGO coordinates in zone $32 \mathrm{~V}$.

the Bjerkreim-Sokndal quartz mangerites, as well as a fine-grained border rock in the Hidra body (Duchesne et al., 1974).

Samples were selected from the various geological units (Fig. 1). They are described in Table 1 and the chemical analyses reported in Table 2 .

\section{Techniques of study}

The rocks have been crushed to $60-250 \mu \mathrm{m}$ and the minerals separated with a Frantz isodynamic magnetic separator and dense liquids (bromoform, methylene iodine, Clerici solution). Crystal faces were indexed by using charts based on the values of the projected angles between edges and the crystallographic axis upon the plane of observation (Caruba, 1975). The unit-cell dimensions were determined with a high precision Seeman-Bohling camera ( $\mathrm{Co} \mathrm{X}$-ray tube, $\mathrm{CaF}_{2}$ as an internal standard). Thermoluminescence curves were obtained with an apparatus in place at Nice University and equipped with a 150 UVP or XP 1020 photomulti- plier. Spectral emissions were studied between 250 and $750 \mathrm{~nm}$ with the help of interference filters with a $15 \mathrm{~nm}$ width at half-height. The samples were heated at a constant $30^{\circ} \mathrm{C} \mathrm{min.}{ }^{-1}$ rate.

Chemical analyses were performed by $\mathrm{X}$-ray fluorescence, with a C.G.R. ALPHA 2020 spectrometer, on Li-borate glass discs for the major elements, and on pressed powders for $\mathrm{Na}$ and $\mathrm{Zr}$, matrix corrections being calculated from the major-element composition. FeO was measured by titration. Wholerock $U$ contents were obtained by neutron activation analysis (Duchesne et al., 1985) or by gamma spectrometry (D. Ormaasen, pers. commun., 1973). A few determinations of $U$ content of zircon were made available by geochronological studies (Pasteels et al., 1979).

U-mapping was obtained by means of a Kapton foil fixed on the polished surface of zircon mounts and irradiated by a total flux of $5 \cdot 10^{4}$ neutrons $\mathrm{cm}^{-2}$.

\section{Chemical composition of the rocks}

The suite of rocks selected in this study displays the classical characteristics of the intermediate and acidic rocks related to massif-type anorthosites (Emslie, 1978); that is: high $\mathrm{FeO} / \mathrm{MgO}$ and $\mathrm{K}_{2} \mathrm{O} / \mathrm{SiO}_{2}$ ratios and alkalic affinities. The Peacock index, determined in the calc-alkali ratio versus silica diagram of Brown (1981), indicates that the monzonorites and, by extrapolation, the acidic rocks are at the limit between alkali-calcic and alkalic suites. The agpaitic coefficient $(\mathrm{Na}+\mathrm{K}) / \mathrm{Al}$ ratio (Table 2) never exceeds 1 even in the most acidic rocks, which therefore can still be considered peraluminous.

The $\mathrm{Zr}$ content of the rocks (Table 2 ) is variable in the monzonorites, and decreases in the Bjerkreim-Sokndal acidic rocks with increasing silica and alkali contents. The U content is usually low (Table 2 ). The $U / \mathrm{Zr}$ ratios increase with the acidity of the rocks. An exception is the Hidra border facies, which is richer in $\mathrm{U}$ and has a higher $\mathrm{U} / \mathrm{Zr}$ ratio than the other monzonorites. The $U$ content of zircon in the Hidra border ( $324 \mathrm{ppm}$ ) is also distinctly higher than in the other samples (e.g., $30 \mathrm{ppm}$ in zircon No. 2). 
Chemical and normative composition of the samples

\begin{tabular}{|c|c|c|c|c|c|c|c|c|c|c|c|c|c|}
\hline & \multirow{2}{*}{$\begin{array}{l}\text { Hidra } \\
1\end{array}$} & \multirow{2}{*}{$\begin{array}{l}\text { Dyke } \\
2\end{array}$} & \multirow{2}{*}{$\begin{array}{l}\text { Apophysis } \\
3\end{array}$} & \multirow{2}{*}{$\begin{array}{l}\text { Dyke } \\
4\end{array}$} & \multicolumn{6}{|c|}{ Bjerkreim-Sokndal } & \multicolumn{3}{|c|}{ Envelope } \\
\hline & & & & & 5 & 6 & 7 & 8 & 9 & 10 & 11 & 12 & 13 \\
\hline $\mathrm{SiO}_{2}$ & 49.96 & 50.80 & 55.63 & 51.35 & 56.34 & 57.27 & 63.07 & 59.83 & 64.72 & 67.75 & 69.44 & 64.22 & 52.29 \\
\hline $\mathrm{TiO}_{2}$ & 4.29 & 2.38 & 2.12 & 2.40 & 2.16 & 1.95 & 1.38 & 1.62 & 0.78 & 0.67 & 0.26 & 0.49 & 1.15 \\
\hline $\mathrm{Al} \mathrm{O}_{3}$ & 14.15 & 13.96 & 14.71 & 15.01 & 12.83 & 11.98 & 13.26 & 13.82 & 14.46 & 13.18 & 15.44 & 16.92 & 15.92 \\
\hline $\mathrm{Fe}_{2} \mathrm{O}_{3}$ & 2.21 & 6.10 & 2.65 & 3.81 & 2.61 & 3.54 & 1.63 & 1.90 & 1.84 & 1.70 & 0.55 & $1.4 !$ & 3.44 \\
\hline $\mathrm{FeO}$ & 11.74 & 9.83 & 9.20 & 10.15 & 11.63 & 10.47 & 6.31 & 8.20 & 5.46 & 4.61 & 2.46 & 3.37 & 11.78 \\
\hline MnO & 0.17 & 0.25 & 0.19 & 0.21 & 0.24 & 0.24 & 0.12 & 0.11 & 0.16 & 0.10 & 0.06 & 0.12 & 0.25 \\
\hline $\mathrm{MgO}$ & 4.92 & 2.17 & 2.11 & 2.22 & 1.75 & 1.52 & 1.40 & 1.62 & 0.33 & 0.66 & 0.20 & 0.48 & 1.09 \\
\hline $\mathrm{CaO}$ & 6.02 & 5.94 & 5.11 & 6.31 & 4.36 & 4.18 & 2.86 & 3.15 & 2.24 & 1.78 & 1.61 & 2.17 & 6.28 \\
\hline $\mathrm{Na}_{2} \mathrm{O}$ & 3.51 & 4.40 & 4.51 & 3.94 & 3.52 & 3.56 & 4.12 & 4.09 & 4.32 & 4.03 & 4.46 & 5.00 & 4.03 \\
\hline $\mathrm{KO}$ & 1.96 & 3.12 & 3.33 & 2.72 & 3.57 & 3.88 & 4.74 & 4.56 & 5.51 & 5.54 & 5.40 & 5.76 & 3.07 \\
\hline $\mathrm{P}_{2} \mathrm{O}_{4}$ & 0.91 & 1.34 & 0.94 & 1.49 & 1.04 & 1.02 & 0.52 & 0.66 & 0.10 & 0.18 & 0.05 & 0.08 & 0.40 \\
\hline Total & 99.83 & 100.30 & 100.50 & 99.61 & 99.45 & 99.61 & 99.40 & 99.57 & 99.92 & 100.22 & 99.93 & 100.02 & 99.70 \\
\hline or & 12.1 & 18.4 & 19.6 & 16.2 & 21.2 & 23.1 & 28.2 & 27.1 & 32.6 & 32.7 & 32.0 & 34.1 & 18.2 \\
\hline$a b$ & 29.8 & 37.1 & 37.9 & 33.4 & 29.8 & 30.1 & 35.0 & 34.7 & 36.5 & 34.0 & 37.7 & 42.2 & 34.2 \\
\hline an & 17.8 & 9.1 & 10.0 & 15.3 & 8.7 & 5.2 & 3.7 & 5.9 & 3.7 & 1.5 & 6.1 & 6.7 & 16.3 \\
\hline $\mathrm{q}$ & - & - & 1.8 & 1.2 & 6.7 & 9.0 & 12.1 & 7.4 & 11.6 & 17.3 & 17.9 & 6.7 & - \\
\hline$c p x$ & 7.0 & 10.5 & 8.3 & 6.3 & 6.0 & 8.2 & 6.4 & 5.0 & 6.0 & 5.4 & 1.4 & 3.1 & 11.0 \\
\hline opx & 16.3 & 6.0 & 12.5 & 14.3 & 17.4 & 13.2 & 8.5 & 12.5 & 5.2 & 5.0 & 3.5 & 4.1 & 5.5 \\
\hline ol & 4.4 & 2.7 & - & - & - & - & - & - & - & - & - & - & 6.8 \\
\hline $\mathrm{mt}$ & 3.1 & 8.8 & 3.8 & 5.5 & 3.8 & 5.2 & 2.4 & 2.8 & 2.7 & 2.5 & 0.8 & 2.0 & 5.0 \\
\hline il & 7.3 & 4.5 & 4.0 & 4.6 & 4.1 & 3.7 & 2.6 & 3.1 & 1.5 & 1.3 & 0.5 & 0.9 & 2.2 \\
\hline ap & 2.2 & 2.9 & 2.0 & 3.3 & 2.3 & 2.2 & 1.1 & 1.5 & 0.2 & 0.4 & 0.1 & 0.2 & 0.9 \\
\hline $\mathrm{Zr}(\mathrm{ppm})$ & 300 & 906 & 890 & 370 & 1610 & 1200 & 800 & 1040 & 690 & 740 & 370 & 830 & 2610 \\
\hline $\mathrm{U}(\mathrm{ppm})$ & 1.2 & 0.39 & & 0.16 & 0.86 & & 1.25 & 0.97 & & 0.66 & & & \\
\hline agp*| & 0.56 & 0.76 & 0.75 & 0.63 & 0.76 & 0.84 & 0.90 & 0.85 & 0.90 & 0.96 & 0.85 & 0.86 & 0.63 \\
\hline$M^{* 2}$ & 2.20 & 2.59 & 2.26 & 2.37 & 2.14 & 2.27 & 1.97 & 1.97 & 1.83 & 1.77 & 1.58 & 1.75 & 2.30 \\
\hline $\begin{array}{c}T(C) \\
\text { zircon } \\
\text { satur. }{ }^{* 3}\end{array}$ & & & & & & & 894 & 922 & 890 & 904 & & & \\
\hline
\end{tabular}

*'agp $=\left(\mathrm{Na}_{2} \mathrm{O}+\mathrm{K}_{2} \mathrm{O}\right) / \mathrm{Al}_{2} \mathrm{O}_{3}($ mole $\%)$ agpaitic coefficient.

*: $\mathrm{M}=(\mathrm{Na}+\mathrm{K}+2 \mathrm{Ca}) /(\mathrm{Si}+\mathrm{Al})($ atom $\%)$.

*'Temperature of zircon saturation for the $\mathrm{Zr}$ content of the magma following Watson and Harrison's (1983) procedure.

\section{Mineralogical and physical properties of zircon}

Table 3 summarizes the various properties of zircon, which are also illustrated in Figs. 2-6.

A common characteristic of all samples is the welldefined prismatic character of the zircon grains together with the almost complete absence of welldeveloped pyramidal or prismatic faces, as already noted by Pasteels and Michot (1975). The terminations of the prism appear either irregular (Fig. 2A and $B$ ) or made up of numerous small faces of high indices (Fig. 2D and F), difficult to index with certainty. Very few grains present sufficiently welldeveloped faces to be indexed (Table 3; Figs. 3 and
4). The rarity of well-developed faces appears not to be due to corrosion processes: no etching figure, embayment or overgrowth of $(\mathrm{Na}, \mathrm{K}) \mathrm{Zr}$-silicates are visible (Caruba et al., 1974). On the contrary, zircon overgrowths are observed on the prismatic faces (Fig. 3D).

Other mineralogical and chemical characters of Tables 2 and 3 permit to divide the samples into several categories:

(1) Zircon from the Hidra monzonoritic facies forms a homogeneous population with a single stage of growth. It shows the highest U content (Fig. 5) and the highest degree of metamictization (Fig. 6). This is consistent with the fact that it has crystal- 
TABLE 3

Mineralogical properties of the zircon populations

\begin{tabular}{|c|c|c|c|c|c|c|c|c|}
\hline \multirow{2}{*}{$\begin{array}{l}\text { Sample } \\
\text { No. }\end{array}$} & \multirow[t]{2}{*}{ Color*1 } & \multirow[t]{2}{*}{ Inclusions*2 } & \multirow[t]{2}{*}{ Zoning } & \multirow[t]{2}{*}{ Core } & \multirow[t]{2}{*}{ U mapping } & \multirow[t]{2}{*}{ Morphology*3 } & \multicolumn{2}{|c|}{ Unit cell ${ }^{* 4}$} \\
\hline & & & & & & & $a(\mathrm{pm})$ & $c(\mathrm{pm})$ \\
\hline 1 & $\mathrm{p}$ to $\mathrm{B}$ & no & no & no & $\begin{array}{l}\text { (not available) ( } 324 \\
\text { ppm) }\end{array}$ & no & 662.8 & 602.9 \\
\hline 2 & c & $A, G, N$ very few & no & no & U-poor (ca. $30 \mathrm{ppm}$ ) & $\{100\}$ or $\{110\}$ & 661.1 & 599.0 \\
\hline 3 & $\mathrm{p}$ & $\begin{array}{l}\text { A.G.N } \\
\text { numerous }\end{array}$ & no & $\begin{array}{l}\text { very } \\
\text { rare }\end{array}$ & $\begin{array}{c}\text { U-poor; rare grains with } \\
\text { a U-richer core }\end{array}$ & $\{100\},\{101\}\{211\}$ & 661.3 & 599.0 \\
\hline 4 & $c$ & $A, G, N$ very few & no & no & $\mathrm{U}$-poor & $\{100\}$ or $\{110\}$ & 661.3 & 598.1 \\
\hline 5 & $c$ & $\mathrm{~A}, G, N$ few & no & no & (not available) & $\{100\},\{101\},\{211\}$ & 661.1 & 599.0 \\
\hline 6 & $\mathrm{p}$ & A.G.N few & no & no & (ibid.) & (ibid.) & 661.1 & 599.0 \\
\hline 7 & $c$ and $P$ & $A, G, N$ few & $\begin{array}{l}\text { c: no } \\
\text { P: yes }\end{array}$ & $\begin{array}{l}\text { no } \\
\text { yes }\end{array}$ & $\begin{array}{l}\text { c: U-poor } \\
\text { P: U-rich parts }\end{array}$ & (ibid.) & 661.3 & 599.7 \\
\hline 8 & $C$ and $P$ & A.G.N few & $\begin{array}{l}\text { c: no } \\
\text { P: yes }\end{array}$ & $\begin{array}{l}\text { no } \\
\text { yes }\end{array}$ & $\begin{array}{l}\text { (ibid.) } \\
\text { (ibid.) }\end{array}$ & (ibid.) & 661.3 & 599.7 \\
\hline 9 & $c$ and $P$ & A.G.N few & $\begin{array}{l}\text { c: no } \\
\text { P: yes }\end{array}$ & no & (ibid.) & $\{100\},\{101\} ?,\{211\} ?$ & 661.3 & 599.7 \\
\hline 10 & $P$ and $B$ & $\begin{array}{l}\text { A.G.N } \\
\text { numerous }\end{array}$ & $\begin{array}{l}\text { P: no } \\
\text { B: yes }\end{array}$ & no & (ibid.) & (ibid.) & 661.1 & 600.0 \\
\hline 11 & $P$ & A,G numerous & $\begin{array}{l}\text { yes } \\
\text { core }\end{array}$ & yes & $\begin{array}{l}\text { high } U \text { average contents } \\
\text { and } U \text {-rich cores }\end{array}$ & $\{100\},\{101\},\{211\}$ & 661.3 & 599.7 \\
\hline 12 & $p$ and $B$ & A.G numerous & $\begin{array}{l}\text { p: no } \\
\text { B: yes }\end{array}$ & $\begin{array}{l}\text { no } \\
\text { yes }\end{array}$ & (ibid.) & $\{100\}$ or $\{110\}$ & 661.3 & 599.7 \\
\hline 13 & $p$ and $B$ & A,G.N few & $\begin{array}{l}\text { p: no } \\
\text { B: yes }\end{array}$ & $\begin{array}{l}\text { no } \\
\text { yes }\end{array}$ & $\begin{array}{c}\text { B: cores are very } \\
\text { enriched in } U\end{array}$ & $\begin{array}{l}\{100\},\{110\} \\
\{101\},\{211\}\end{array}$ & 661.1 & 599.8 \\
\hline
\end{tabular}

${ }^{*} \mathrm{c}=$ colourless; $\mathrm{p}=$ pale pink; $\mathrm{P}=$ brownish pink; $\mathrm{B}=$ brown.

* $\mathrm{A}=$ circular: $\mathrm{G}=$ globular: $\mathrm{N}=$ negative crystals.

* Faces identified on the few crystals which could be indexed

${ }^{*}$ Accuracy of $\pm 0.5 \mathrm{pm}$.

lized in an environment richer in $U$ than the other occurrences.

(2) Zircon from the other monzonorites and related rocks (Nos. 2-6) was also formed in a single stage of growth. It is unzoned, devoid of a core and, in contrast with zircon from Hidra, is well crystalline (lattice parameters, Fig. 5; thermoluminescence, Fig. 6). U content is low and uniformly distributed. These crystals have formed in a U-poor melt, with a low content of volatiles. It must be mentioned that sample No. 3 (coarse-grained monzonite from the Apophysis) contains a small amount of grains with U-rich cores. These could have been inherited in small amounts from a more U-rich population, and the host rock might therefore have a more complex history than the other monzonorites.

(3) Zircon from the Bjerkreim-Sokndal quartz mangerites is present in two distinct populations: (a) clear (colourless to brown-rose, unzoned), Upoor crystals, which constitute the most important population; and (b) thicker crystals with a U-rich zoned core and a clear envelope, which are rather frequent. It is obvious from the $\mathrm{U}$ content and the general appearance that the clear-type of zircon and the envelope of the zoned crystals belong to the same generation.

(4) All zircon populations from the metamorphic envelope are also heterogeneous and present grains with a U-rich core. They have a higher average $U$ content than the Bjerkreim-Sokndal zircon and the contrast between core and envelope is greater.

\section{Discussion}

The lack of well-developed pyramidal faces is an indication of growth in a dry environment, as shown experimentally (Caruba, 1975, 1978; Caruba et al., 1975). This fact is in agreement with the conditions of formation of charnockitic rocks in granulite facies (Janardhan et al., 1982).

Two possible mechanisms can account for the systematic presence of a U-rich core in zircon from acidic igneous and metamorphic rocks: (1) rapid 


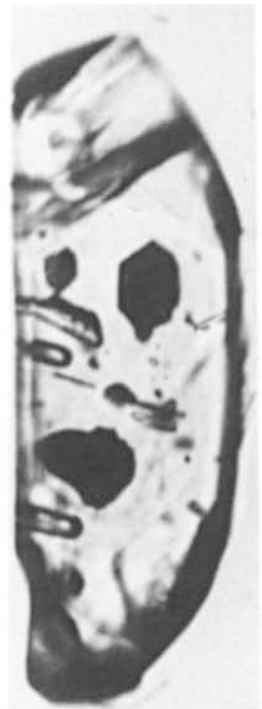

A

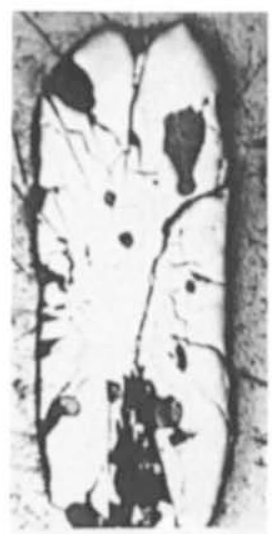

E

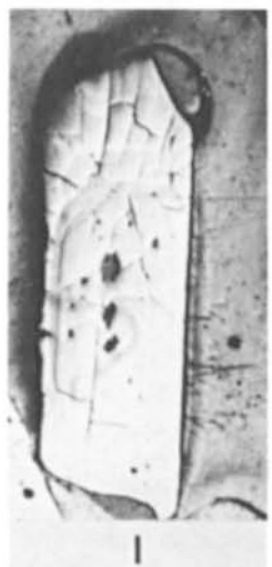

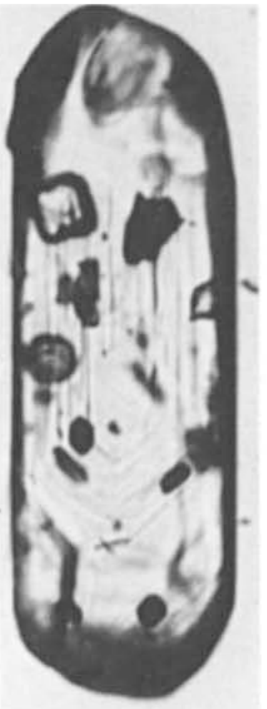

B

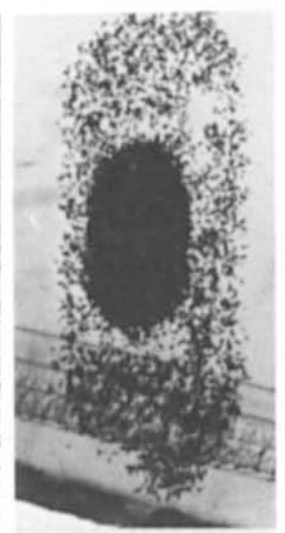

F

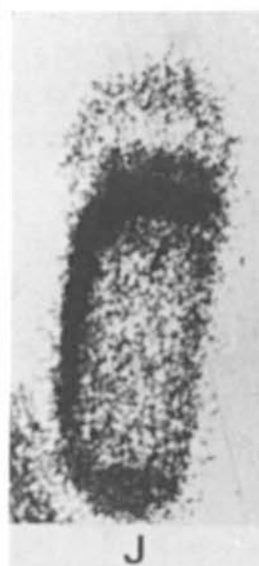

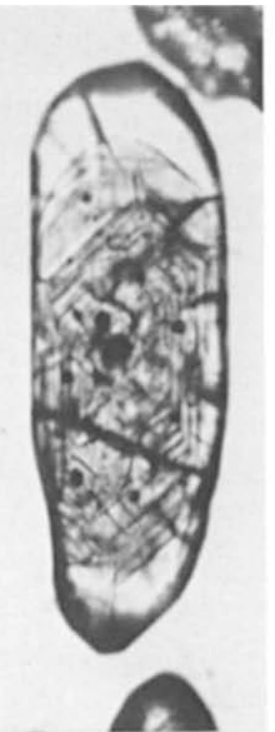

C

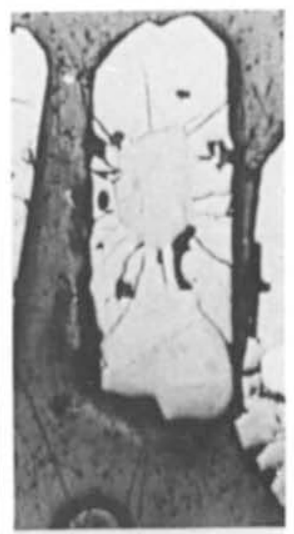

G

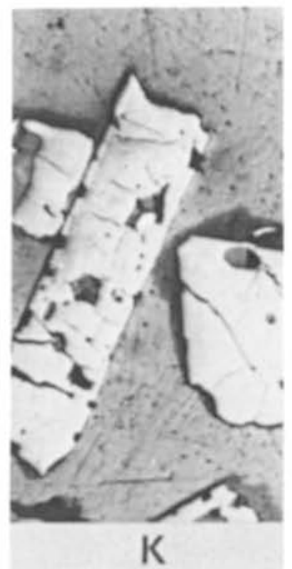

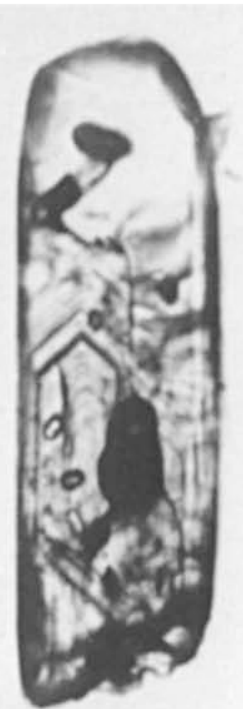

D

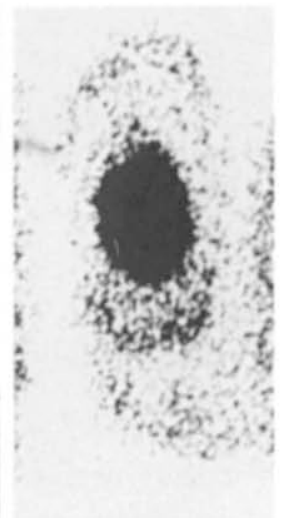

H

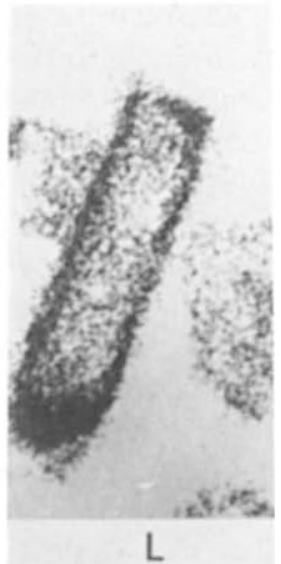

Fig. 2. Zircon crystals (average length $150-250 \mu \mathrm{m}$ ).

A. Unzoned colourless grain showing various types of inclusions (No. 9: quartz mangerite).

B. Zoned grain with inclusions (No. 8: quartz mangerite).

C. Zoned innerpart of coloured core and external clear envelope (No. 11: quartz mangerite gneiss) 

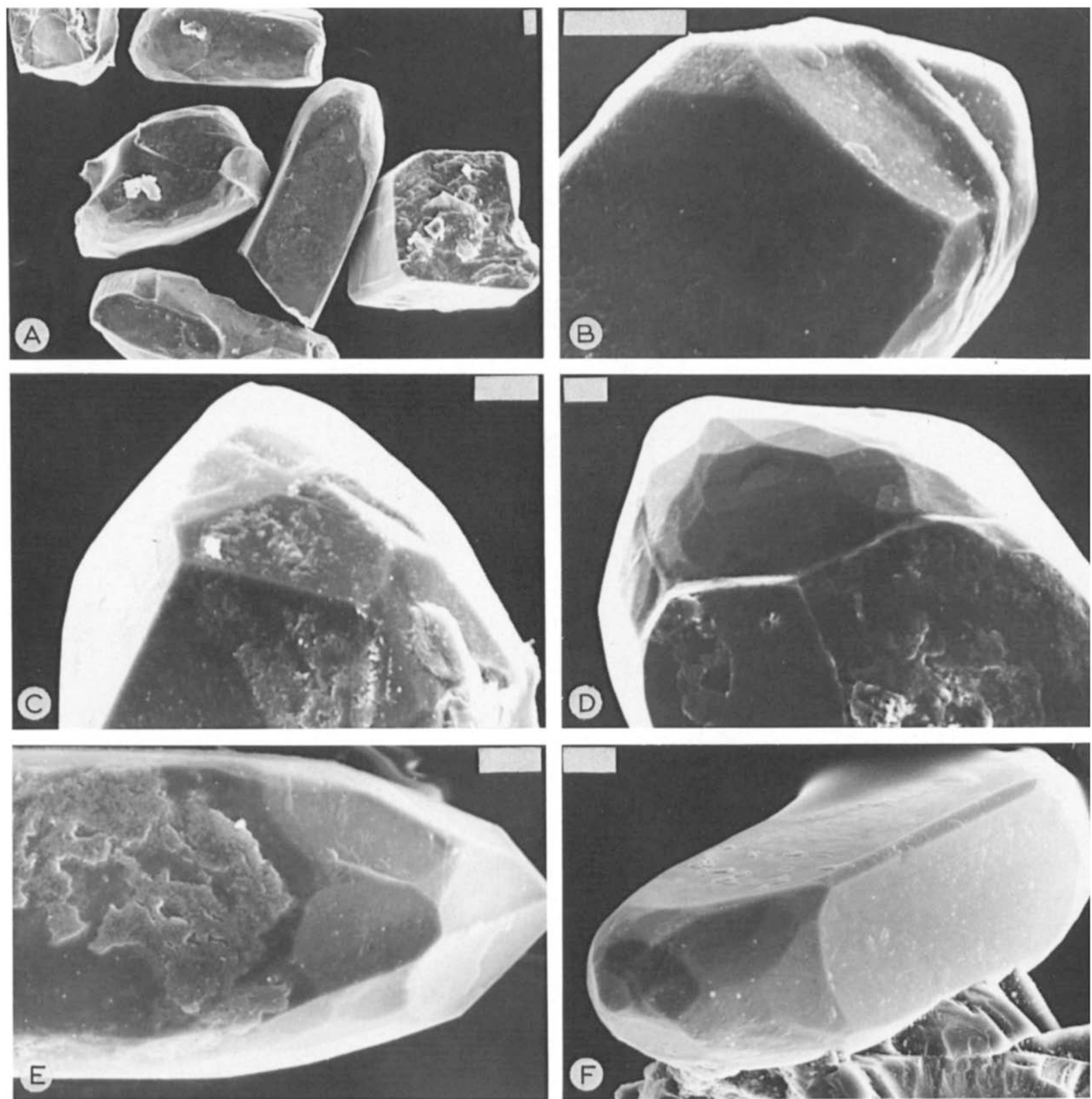

Fig. 3. Zircon morphology - The scale is indicated by the white bar, which represents $10 \mu \mathrm{m}$.

A. Irregular grains and fragments of prismatic crystals $\{100\}$ or $\{110\}$ faces, showing "rounded" terminations (sample No. 4: monzonorite).

B. Complex termination of a prismatic grain showing an ill-defined pyramid, a curved face and irregular overgrowth (sample No.

5: monzonorite).

C. Well-developed $\{211\}$ faces terminating in a badly-formed $\{101\}$ pyramid (sample No. 8: quartz mangerite).

D. Prism-ending showing numerous small faces of high indices. The faces of the prism are coated by a layer of zircon, a growth process that suggests a dry melt environment (sample No. 3: monzonorite).

E. $\{100\}$ prisms with $\{201\}$ and $\{211\}$ pyramids (sample No. 13: monzonite gneiss).

F. $\{100\}$ and (small) $\{110\}$ prism faces with multi-faced pyramidal terminations (sample No. 13: monzonite gneiss).

D. Complex zoning of the innerpart and clear envelope (No. 13: monzonite gneiss).

E-L. Polished sections of complex zircon grains showing core and crackled envelope and corresponding $U$ distribution obtained by the U-mapping technique. All grains from the same sample (No. 7: quartz mangerite). As a rule the $U$ content of the most external zone is always low and high $\mathrm{U}$ contents coincide with the core $(\mathrm{F}$ and $\mathrm{H})$, or with one or several zones surrounding a $\mathrm{U}$ poor innermost part $(\mathrm{J}$ and $\mathrm{L})$. 


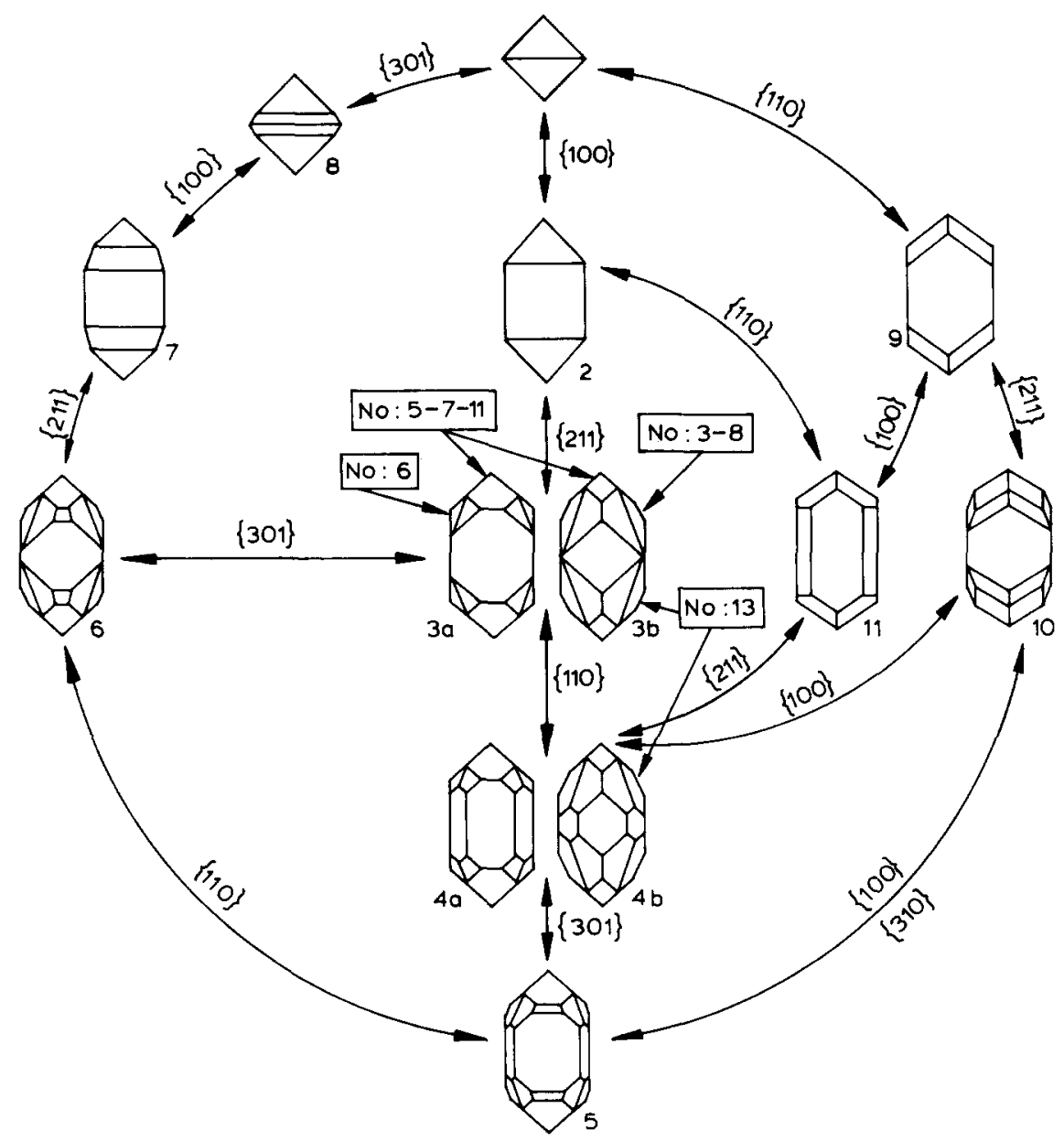

Fig. 4. Zircon morphology. The various types of crystals identified are indicated on the classification of Caruba (1983), which is mainly based on the order of crystal faces appearance according to the crystallographic laws of Donnay-Harker (types 1 to 5 ) and on the relative development of some faces (types $3 a$ and $3 b ; 4 a$ and $4 b$ ). It also takes into account the possible influence of impurities that can induce appearance or disappearance of new faces in types 1 to 5 . This classification minimises the effects of a possible asymmetrical development of faces. The number in the boxes refers to the samples.

variation in the $U$ activity during continuous crysallization of the rock; (2) heritage of partially undissolved zircon from other rocks. There is no petrologic indication to support the first explanation. No other U-rich mineral is present. Apatite contains some $\mathrm{U}$ but in very low amounts (as qualitatively checked by U-mapping on rock samples), and it is a mineral always present in quartz mangerite as well as in monzonorite. Biotite is absent and a late-stage amphibole occurs in small amounts variable from rock to rock.

On the other hand two facts strongly suggest heritage of xenocrysts. Firstly, quartz mangerite No. 8 contains some cores with a U-poor central part (Fig. $2 \mathrm{I}$ and $\mathrm{K}$ ). Such a feature is more easily explained if xenocrysts come from various sources than by postulating a very early stage of growth with a low $\mathrm{U}$ activity followed by an abrupt increase and, eventually, by a decrease in $\mathrm{U}$ activity. Secondly, $\mathrm{Zr}$ compositions proved to be zircon-oversaturated in the Bjerkreim-Sokndal quartz mangeritic magma. Indeed, Watson and Harrison (1983) have suggested on experimental grounds that the solubility of zircon in peraluminous magmas is controlled by temperature and the contents of alkalis, calcium, silicium and aluminium ( $M$ coefficient of Table 2 ). Crystallization temperatures of about $1050^{\circ} \mathrm{C}$ for the monzonorites have been deduced in the Lomland dyke from apatite saturation (Duchesne et al., 1985). In Bjerkreim-Sokndal quartz mangerites, a 


\section{$\overrightarrow{\mathbf{a}}$}

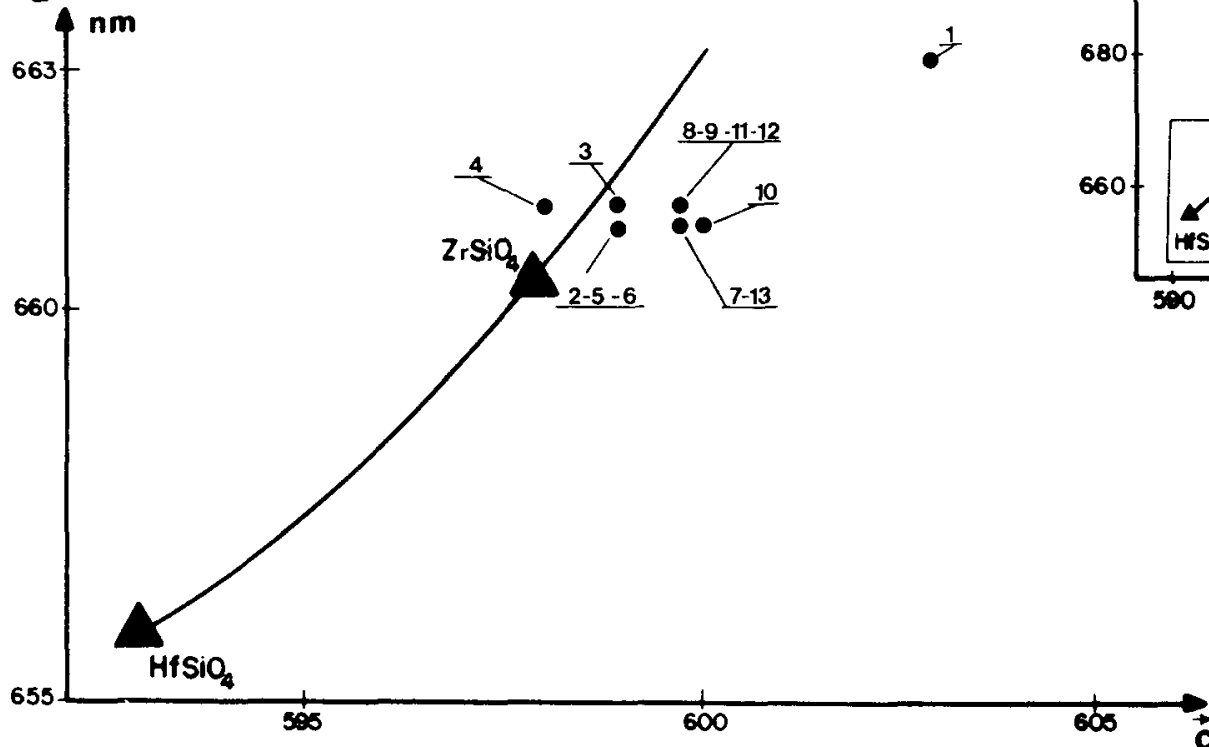

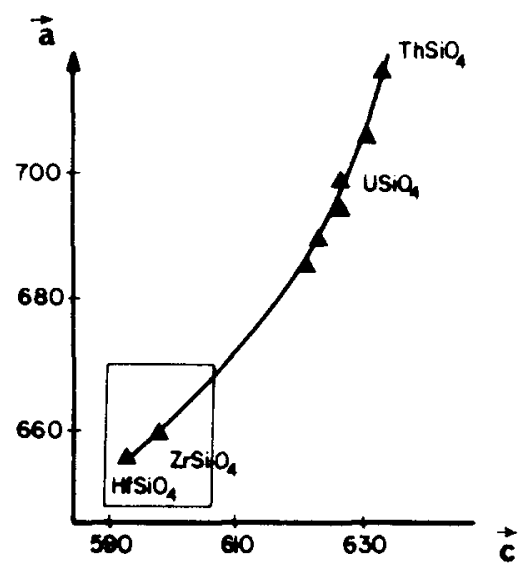

Fig. 5. Plot of the $a$ versus $c$ parameter in zircon. Values determined for samples Nos. 2 to 6 (monzonorites) plot near the values of pure synthetic $\mathrm{ZrSiO}_{4}$ (Caruba et al., 1975) and are consistent with low U content (ca. 30 ppm) and high purity (lack of core and zoning, colourless or pale pink) (see Table 3). Zircon No. 1 (Hidra monzonorite) has larger cell dimensions, correlated with a higher $\mathrm{U}$ content $(324 \mathrm{ppm})$ in the $\mathrm{ZrSiO}_{4}-\mathrm{USiO}_{4}$ solid solution, a higher intensity of the colour and a slight metamict stage, well shown by thermoluminescence (Fig. 6). Cell dimensions for samples Nos. 7-13 (quartz mangeritic igneous and metamorphic rocks) are average values of a bimodal population. They are logically higher than those of U-poor pure zircon because of the influence of the U-rich core.

range of $800-830^{\circ} \mathrm{C}$ has been obtained by means of Lindsley and Anderson's two-pyroxenes geothermometer, which is consistent with Fe-Ti oxide geothermometer determinations (Duchesne, 1972; Wilmart and Duchesne, 1988). $\mathrm{Zr}$ content of the magma at zircon saturation, following Watson and Harrison's (1983) procedure (Table 2), is about $4000 \mathrm{ppm} \mathrm{Zr}$ in the Lomland dyke (sample No. 4) and $300-360 \pm 50 \mathrm{ppm} \mathrm{Zr}$ in Bjerkreim-Sokndal acidic rocks (sample Nos. 7-10). This clearly suggests on the one hand that zircon did not crystallize at the liquidus of monzonoritic magma and, on the other hand, that it was largely in excess over its saturation value in Bjerkreim-Sokndal quartz mangeritic magma. Although these figures must be considered with some prudence because of uncertainties in the temperature estimates, of the strong influence of temperature on zircon solubility (zir- con in sample Nos. $7-10$ is completely soluble at temperatures in excess of $890-920^{\circ} \mathrm{C}$ - see Table 2 ), and of the possible influence of other major elements on the $\mathrm{Zr}$ solubility in the magma, it is interesting to note that oversaturation in zircon occurs in rocks where zircon exhibits a core. Therefore heritage of partially undissolved zircon grains seems the most likely explanation to the presence of cores.

Heritage of the cores suggests two processes for the generation of the acidic rocks:

(1) Dry anatexis of metamorphic rocks. Owing to their refractory nature the inherited grains are unmelted relics from the source rock. It must be noted that the anatectic melt has crystallized a zircon poorer in $U$ than the inherited grains. This suggests a change in the $U / Z r$ ratio of the melt and tends to indicate that the "flushing out" of the $U$, a feature typical of granulite facies metamorphism 


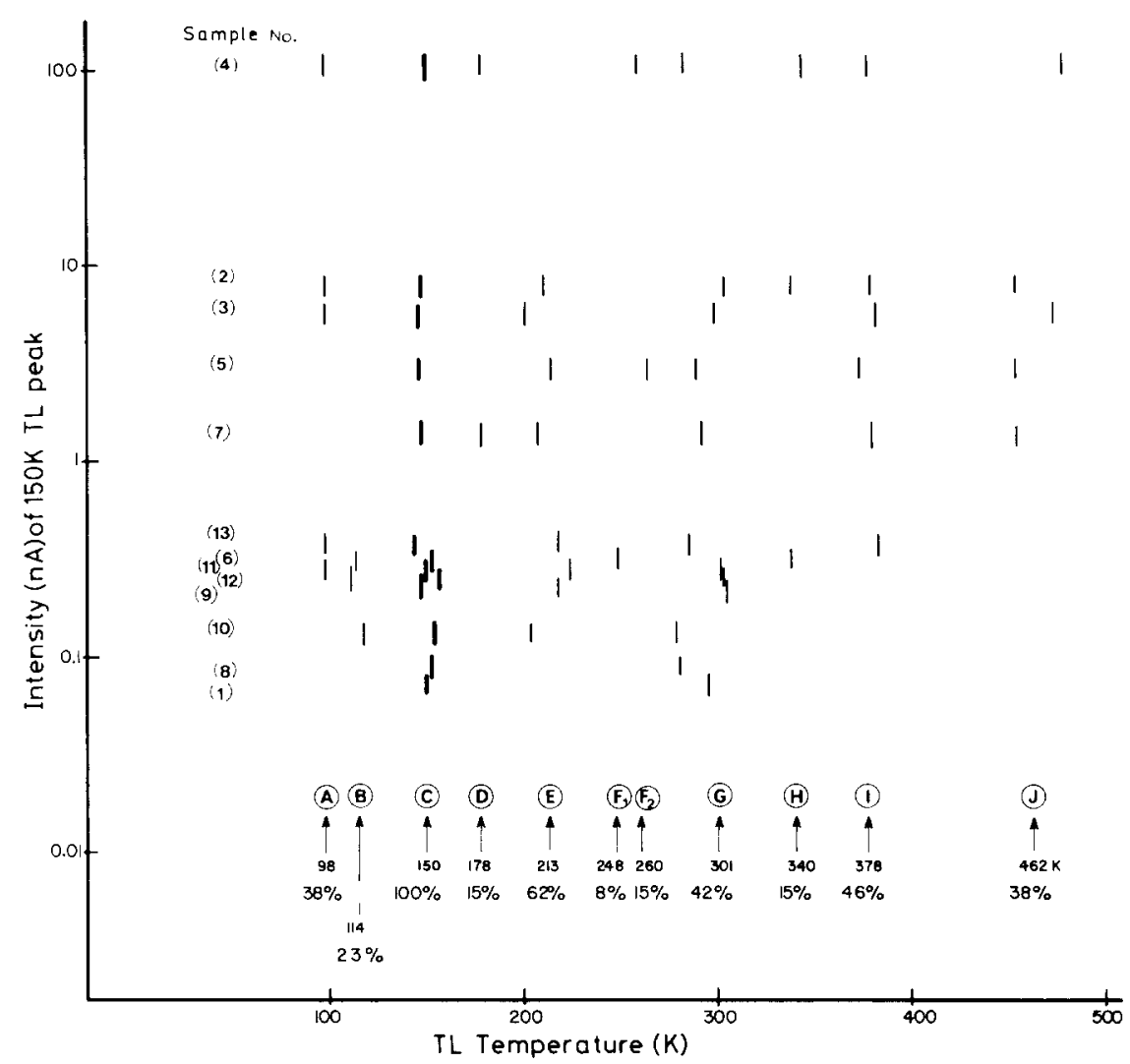

Fig. 6. Thermoluminescence (TL) spectra: plot of the intensity of the most intense thermoluminescence peak (ca. $150 \mathrm{~K}$ ) against the temperature of the other peaks in the various samples. Each peak is designated by a letter. The average temperature of emission is indicated under the arrow, as well as the frequency of appearance (\%). The intensity varies by three orders of magnitude and is inversely correlated with the metamictization degree of zircon, as shown by Caruba and Iacconi (1983). A detailed study of the spectral emission of the $150 \mathrm{~K}$ peak of the less metamict samples Nos. 4 and 2 (monzonoritic dykes) has revealed the presence of $\mathrm{OH}$ groups in sample No. 2 (faint $285 \mathrm{~nm}$ emission band) and its absence in sample No. 4, thus confirming the sensitivity of the method to characterize very low degrees of metamictization (Iacconi and Caruba, 1977; Iacconi et al. 1980).

(Collerson and Fryer, 1978), might possibly have taken place during anatexis.

(2) Bulk contamination either by assimilation of zircon-bearing material or by mixing of magmas. In the first case the cores would represent relics from the contaminant, unassimilated by a magma residual to anorthosite formation. In the case of mixing, one magma can be residual to anorthosite formation and the other be produced by anatexis.

Truncation of $U$-rich zones by envelopes in some Bjerkreim-Sokndal zircons (Fig. 2J) and the general rounded appearance of cores (Fig. 2D and $\mathrm{H}$ ) suggest either that the cores are of detritic origin or that they were corroded prior to their final growth in the oversaturated magma. In an anatectic process, the corrosion results from the melting process itself and, in bulk contamination, can be explained by a possible stage of evolution of the magma at a temperature higher than that of consolidation. It has been shown (Table 2) that an increase in the temperature of the quartz mangeritic magma of Bjerkreim-Sokndal to $890-920^{\circ} \mathrm{C}$ is sufficient to completely dissolve the quantity of zircon in excess over the solubility at the crystallization temperature. The difference of about $90^{\circ} \mathrm{C}$ in temperature does not appear incompatible with a mixing process in which the magmas have different temperatures or with assimilation at a temperature higher than that of crystallization.

Isotope fractionation (Morse, 1983), selective contamination process (Moorbath and Thompson, 1980) and fluid circulation (Dickin, 1981) leading 
to isotopic re-equilibration have been suggested as possible mechanisms to account for an increase in the initial $\mathrm{Sr}$ isotopic ratio without bulk contamination. It is clear from the present data that such processes are unable to explain the presence of inherited zircon. Moreover, though an increase in the $\mathrm{Sr}$ isotopic ratio by any of these mechanisms cannot be ruled out, bulk contamination or anatexis appear as more straightforward explanations. With the present state of knowledge, it remains difficult to assess the relative importance of anatexis and bulk contamination. It must however be pointed out that the absence of inherited zircon cannot, by any means, be invoked to rule out a contamination process or a crustal anatexis. Zircon might indeed be absent from the contaminant or from the source rock, or have been completely melted or dissolved in the magma at high temperatures.

In the classical example of the Rogaland anorthosite suite of rocks - the Bjerkreim-Sokndal lopolith -, zircon data clearly show that quartz mangerites and monzonorites are not comagmatic, in the sense that they do not result from fractional crystallization in a closed system, without any addition of exotic material. But this does not necessarily mean that acidic rocks in general cannot be produced by closed-system fractionation. The Lomland dyke is a well-documented case of fractionation without contamination (Duchesne et al., 1985), associating norites and monzonorites to quartzbearing varieties.

The origin of the quartz mangerite gneisses of the envelope is still debatable. Zircon data tend to show that they have many features in common with Bjerkreim-Sokndal quartz mangerites. However, a charnockitic anatexis with flushing-out of the $U$ is more likely than anorthosite derivation, because it can match the $1200 \mathrm{Ma}$ metamorphic age without postulating an unknown anorthositic event older than $1000 \mathrm{Ma}$. Clearly, however, the zircon data cannot completely rule out such a hypothesis.

In the monzonorite family, differences can be detected between occurrences. For instance, the Hidra border facies differs from dyke rocks by the $U$ content of its zircon and also by several mineralogical properties. This confirms what has already been noted on the basis of major and trace elements (Duchesne et al., 1985) and must reflect different source rocks. Another instance is the presence of U- rich zircons in the coarse-grained rock-type of the Apophysis.

\section{Conclusions}

In zircon from charnockitic rocks, the lack of welldeveloped pyramidal faces is not due to corrosion but suggests a dry formation environment, consistent with granulite-facies conditions.

The $U$ content of zircon is correlated with intensity of colour, crystal lattice parameters and degree of metamictisation. Zircons from monzonoritic rocks in Rogaland are usually clear, nearly perfectly crystalline and U-poor, except in the Hidra body. This exception points to different sources for the monzonoritic magmas.

Though zircon morphology gives poor indications, the presence or absence of a core can be revelatory. In the quartz mangeritic magma of the Bjerkreim-Sokndal lopolith, the $\mathrm{Zr}$ content is higher than the zircon saturation at liquidus temperature, and the zircons exhibit brownish cores. These are considered as inherited through crustal anatexis or bulk contamination. Both processes can account for the fact that the initial $\mathrm{Sr}$ isotopic ratio is higher in these rocks than in the lower part of the lopolith.

\section{Acknowledgments}

Ms. C. Pierlot and Dr. J.M. Peters (Liège) contributed to the preparation of the U-mapping technique. G. Bologne and G. Delhaze (Liège), T. Fromage and R. Morin (Nice) provided valuable assistance. Robert F. Martin greatly improved an early version of the paper. The chemical analyses were made in the "Collectif Interuniversitaire de Géochimie Instrumentale" (Liège). The Belgian F.N.R.S. and the French C.N.R.S. have supported the project.

\section{References}

Brown, G.C., 1981. Space and time in granite plutonism. Philos. Trans. R. Soc. London, Ser. A, 301: 321-336.

Buddington, A.F., 1939. Adirondack igneous rock and their metamorphism. Geol. Soc. Am. Mem., 7: 1-345.

Caruba, R., 1975. Étude expérimentale de la cristallographie, de la morphologie, de la stabilité et de la genèse du zircon et des zirconosilicates en vue d'applications pétrogéné- 
tiques. Thesis, University of Nice, Nice, $324 \mathrm{pp}$.

Caruba, R., 1978. Morphologie de zircons synthétiques Corrélations pétrogénétiques. Can. Mineral., 16: 31 5-323.

Caruba, R., 1983. Zircon morphology. 2nd Eur. Union Geochem. Meet., Strasbourg, Terra Cognita, 3(2-3): 161 (abstract).

Caruba, R. and Iacconi, P., 1983. Les zircons de Narssârssuk (Groënland) - L'eau et les groupements $\mathrm{OH}$ dans les zircons métamictes. Chem. Geol., 38: 75-92.

Caruba, R., Dars, R., Mano, J. and Turco, G., 1974. Corrosions expérimentales de cristaux de zircons rencontrés dans les granites albitisés. Tschermaks Mineral. Petrogr. Mitt., $21: 33-46$.

Caruba, R., Baumer, A. and Turco, G., 1975. Nouvelles synthèses hydrothermales du zircon: substitutions isomorphiques; relation morphologie-milieu de croissance. Geochim. Cosmochim. Acta, 39: 11-26.

Collerson, K.D. and Fryer, B.J., 1978. The role of fluids in the formation and subsequent development of early continental crust. Contrib. Mineral. Petrol., 67: 151-167.

Demaiffe, D., Duchesne, J.C. and Hertogen, J., 1979. Trace element variations and isotopic composition of charnockitic acidic rocks related to anorthosites (Rogaland, S.W. Norway). In: L.H. Ahrens (Editor), Origin and Distribution of The Elements. Pergamon, Oxford, pp. 417-429.

Dickin, A.P., 1981. Isotope geochemistry of Tertiary igneous rocks from the Isle of Skye, N.W. Scotland. J. Petrol., 22: 155-189.

Duchesne, J.C., 1972. Iron Titanium oxide minerals in the Bjerkrem-Sogndal massif (Southwestern Norway). J. Petrol., 13: 57-81

Duchesne, J.C., Roelandts, I., Demaiffe, D., Hertogen, J., Gijbels, R. and De Winter, J., 1974. Rare-earth data on monzonoritic rocks related to anorthosites and their bearing on the nature of the parental magma of the anorthositic suite. Earth Planet. Sci., Lett., 24: 325-335.

Duchesne, J.C., Roelandts, I., Demaiffe, D. and Weis, D., 1985. Petrogenesis of monzonoritic dykes in the Egersund-Ogna anorthosite (Rogaland, S.W. Norway): trace elements and isotopic $(\mathrm{Sr}, \mathrm{Pb})$ constraints. Contrib. Mineral. Petrol., 90: 214-225.

Emslie, R.F., 1978. Anorthosite massifs, Rapakivi granites, and late Proterozoic rifting of North America. Precambrian Res., 7: 61-98.

Hermans, G.A.E.M., Tobi, A.C., Poorter, R.P.E. and Maijer, C., 1975. The high-grade metamorphic Precambrian of the Sirdal-Orsdal area, Rogaland/Vest-Agder, S.W. Norway. Nor. Geol. Unders., (Publ.), 318: 51-74.

Iacconi, P. and Caruba, P., 1977. Sur le rôle des $\mathrm{OH}$ dans l'émission de thermoluminescence du zircon $\mathrm{Zr}\left(\mathrm{SiO}_{4}\right)_{1-x}(\mathrm{OH})_{4 \times r}$ synthétique. C.R. Acad. Sci., Paris, 285(9): 227-231

Iacconi, P., Deville, A. and Gaillard, B., 1980. Trapping and emission centres in X-irradiated zircon, I. Contribution of the OH ion. Phys. Status Solidi, A, 59: 139-146.

Janardhan, A.S., Newton, R.C. and Hansen, E.C., 1982. The transformation of amphibolite facies gneiss to charnock- ite in southern Karnataka and northern Tamil Nadu, India. Contrib. Mineral. Petrol., 79: 130-149.

Michot, J. and Michot, P., 1969. The problem of the anorthosites. The South Rogaland igneous complex (South Western Norway). In: Y.W. Isachsen (Editor), Origin of Anorthosites and Related Rocks. N.Y. State Mus. Sci. Serv., Mem., 18: 399-410.

Michot, P., 1960. La géologie de la catazone: le problème des anorthosites, la palingenèse basique et la tectonique catazonale dans le Rogaland méridional (Norvège méridionale). Nor. Geol. Unders., (Publ.), 212 (g): 1-54.

Michot, P., 1965. Le magma plagioclasique. Geol. Rundsch., 54: $956-976$.

Michot, P., 1966. Carte tectonique de la région comprise entre Ålgård et le Lakssvelefjeld. Guideb., AZOPRO Meet. in the Rogaland, (unpublished).

Moorbath, S, and Thompson, R.N., 1980. Strontium isotope geochemistry and petrogenesis of Early Tertiary lava pile of the Isle of Skye, Scotland, and other Provinces: an example of magma-crust interaction. J. Petrol., 21: 295-321.

Morse, S.A., 1983. Strontium isotope fractionation in the Kiglapait intrusion. Science, 220: 193-195.

Pasteels, P. and Michot, J., 1975. Geochronological investigation of the metamorphic terrain of South-Norway. Nor. Geol. Tidsskr., 55: 111-134.

Pasteels, P., Demaiffe, D. and Michot, J., 1979. U-Pb and $\mathrm{Rb}-\mathrm{Sr}$ geochronology of the eastern part of the South Rogaland igneous complex, Southern Norway. Lithos, 12: 199-208.

Streckeisen, A., 1974. How should charnockitic rocks be named? In: J. Bellière and J.C. Duchesne (Editors), Géologie des Domaines Cristallins. Centen. Soc. Géol. Belg., Liège, pp. 349-360.

Watson, B. and Harrison, M., 1983. Zircon saturation revisited: temperature and composition effects in a variety of crustal magma types. Earth Planet. Sci. Lett., 64: 295-304.

Wendlandt, R.F., 1981. Influence of $\mathrm{CO}_{2}$ on model granulite facies assemblage: a model for the genesis of charnockites. Am. Mineral., 66: 1164-1174.

Wiebe, R.A., 1984. Commingling of magmas in the Bjerkrem-Sokndal lopolith (southwest Norway): evidence for the compositions of residual liquids. Lithos, 17: 171-188.

Wielens, J.B.W., 1979. Morphology and U-Pb ages of zircons from the high-grade metamorphic Precambrian in the Sirdal-Örsdal area, SW Norway. Verh. ZWO Lab. IsotopenGeol., Amsterdam, No. 4.

Wielens, J.B.W., Andriessen, P.A.M., Boelrijk, N.A.I.M., Hebeda, E.H., Priem, H.N.A., Verdurmen, E.A.Th. and Verschure, R.H., 1981. Isotope geochronology in the highgrade metamorphic Precambrian of Southwestern Norway: new data and reinterpretations. Nor. Geol. Unders., (Publ.), 359: 1-30.

Wilmart, E. and Duchesne, J.C., 1988. Geothermobarometry of igneous and metamorphic rocks around the Ana-Sira anorthosite massif: Implications for the depth of emplacement of the South Norwegian anorthosites. Nor. Geol. Tidsskr. (in press). 